\title{
Beliefs About Scientific Creativity Held by Pre-Service Science Teachers in the State of Kuwait
}

\author{
Hamed Jassim Alsahou ${ }^{1}$ \& Ahmad Shallal Alsammari ${ }^{1}$ \\ ${ }^{1}$ College of Basic Education, The Public Authority for Applied Education and Training, Kuwait \\ Correspondence: Hamed Jassim Alsahou, College of Basic Education, The Public Authority for Applied \\ Education and Training, Kuwait.
}

Received: May 8, 2019

doi:10.5539/ies.v12n10p37
Accepted: July 13, 2019 Online Published: September 29, 2019

URL: https://doi.org/10.5539/ies.v12n10p37

\begin{abstract}
Understanding teachers' sentiments and views is a central goal of the educational research community; especially, understanding teachers' beliefs which could be transferred to classroom practices. Teachers' beliefs about creativity and how they can nurture it has been investigated in several studies, but there is a lack of studies exploring teachers' beliefs about creativity in the science classroom. The current study aims to understand the beliefs of pre-service science teachers about scientific creativity, fostering creativity in the science classroom, the characteristics of creative students in science, and the encouraging and challenging factors. The research design has an exploratory nature based on a questionnaire consisting of 18 closed-ended questions and eight open-ended questions. 152 questionnaires were quantitatively and qualitatively analyzed. The results indicated that science is seen as a creative school subject. Participants view scientific creativity as original, useful, imaginative, and having empirical actions. Commitment, curiosity, enthusiasm, questioning, and experimenting are the characteristics of creative students in the science classroom. Other factors that encourage or hinder the process of nurturing scientific creativity were also identified. Implementations and suggestions for future study are also discussed.
\end{abstract}

Keywords: scientific creativity, nature of science, teachers' beliefs, science classroom, Kuwait

\section{Introduction}

Creativity is one of the fundamental goals in education, pursued by many countries around the world, because creativity is one of the crucial aspects for developing advanced societies (Hennessey \& Amabile, 2010). In the State of Kuwait, the current government has established a national program called New Kuwait 2035, aimed at developing new infrastructure for all national services including education. The new program prioritizes creative education in order to confront future challenges.

Although the existing literature on creativity identifies many aspects, elements, and implications, few studies investigate teachers' conceptions of creativity and how it can be nurtured. Andiliou and Murphy (2010) reviewed research on creativity published between 2000 and 2009; they found only nine studies focused on teachers' perspectives about creativity, and only one study out of the nine concerned teachers' perspectives on creativity in science education. The science education literature suffers from a lack of research about fostering scientific creativity and how teachers understand creativity in the science classroom (Liu \& Lin, 2014). Thus, there is a need for further investigation about teachers' conceptions of creativity in the science classroom.

\subsection{Creativity in Science Education}

Research concludes that creativity can be nurtured in numerous fields (Andiliou \& Murphy, 2010); however, creativity is domain-specific. In other words, creativity can be understood differently based on the nature of the domain. Consequently, teaching for creativity, creativity assessment, and creative learning can be affected by the nature of the subject taught. For instance, some studies have found that teachers associate creativity more with art and music education than with subjects such as science and math (e.g., Aljughaiman \& Mowrer-Reynolds, 2005; Diakidoy \& Kanari, 1999; Fryer, 1996; Kampylis, 2010; Mohammed, 2006).

The reason for this is that teachers misunderstand the nature of science (NoS) by believing that science consists of unchangeable universal laws and groups of absolute facts. Such a misunderstanding could lead to teaching science as purely objective subjects to the students (Johnston, 2009; Osborne \& Dillon, 2008). Meanwhile, the 
NoS is tentative, theory-laden, creative, empirical, and socially and culturally embedded (Abd-Elkhalick \& Lederman, 2000). In a nutshell, creativity is implanted within the process of constructing scientific knowledge, starting from suggesting hypotheses, planning, collecting, analyzing, interpreting data, solving problems, forming theories, and assuming facts (Lin, Adey, \& Shen, 2003).

\subsection{Teachers' Beliefs About Creativity}

Beliefs are the personal perceptions that help an individual understand the world and him/herself (Pajares,1992). Beliefs are also considered as the connotations held by individuals about phenomena that mediate their interactions with contexts relating to those phenomena (Pratt, 1992). Consequently, teachers' beliefs are a very important matter. Many scholars have argued that teachers' practices, decisions, administration style, and assessments could be influenced by their beliefs (Pajares, 1992; Richardson, 1996; Thompson, 1992; Woolley, Benjamin, \& Woolley, 2004). In other words, teachers are likely at times to put their beliefs into their teaching practices (Shin \& Koh, 2007).

Pedagogical practices that nurture creativity in the science classroom could be based on what the science teacher believes about creativity. Alsahou (2015), for example, investigated eight case studies of science teachers and concluded that a teacher who believed that science is a static and non-creative subject usually built his/her practices on teacher-centered approaches. Meanwhile, science teachers who hold progressive beliefs about creativity were applying more student-centered approaches and encouraging imaginative thinking. Therefore, teachers' beliefs play a significant role, for their beliefs about creativity can facilitate or hinder the creative thinking of students inside the classroom (Beghetto, 2006).

Previous research has indicated that science teachers hold a general understanding of creativity and can identify some major components of creativity. However, they appeared to have naïve beliefs about deeper issues concerning creativity. For example, a study conducted by Liu and Lin (2014) investigated the beliefs of 16 experienced science teachers about creativity. The study found that the teachers were able to explain some pedagogies for teaching creativity in the science classroom as well as some characteristics of creative students. Nevertheless, Liu and Lin (2014) concluded that the experienced teachers missed out some other aspects of creativity and some pedagogies, such as problem-solving skills and convergent thinking skills.

Lee and Kim (2005) also studied science teachers' beliefs about creativity among teachers in a program for gifted students in South Korea. They found that teachers limited the meaning of creativity to high cognitive and intellectual capacities; the teachers also neglected the role of environmental factors on creative behaviors. Hong and Kang (2010) found that science teachers hold restricted beliefs about creativity, concluding that the teachers believed that problem-based learning and inquiry-based learning can foster creativity in the science classroom. However, the researchers argued that the teachers could not elaborate on their general beliefs.

Other studies have aimed to explore the beliefs about creativity of pre-service student teachers who will become science teachers. For example, Newton and Newton (2011) explored the beliefs of 79 pre-service science teachers, and concluded that trainers hold simple and narrow beliefs about creativity in science. The participants focused on hands-on activities as a facilitator approach for nurturing creativity. Such understanding is simple because one approach does not address individual differences and needs. Newton (2010) also asked 12 pre-service science teachers to assess the creativeness of selected events; the results indicated that overall assessment criteria used by participants to evaluate the event were naïve. One year previously, Newton and Newton (2009) found that pre-service science teachers hold insufficient beliefs about creativity, and they missed out the role of imaginative thinking in constructing scientific knowledge. Similarly, Park, Lee, and Oliver (2006) concluded that student teachers have simple beliefs.

Overall, the reviewed studies found that teachers agreed that creativity can be nurtured in the science classroom; but that they hold simple and insufficient beliefs about some aspects of creativity, nurturing creative behaviors, and how to assess creativity in the science classroom.

\subsection{Questions of the Study}

The current study aimed to assess the beliefs of pre-service science teachers about creativity in the science classroom. Four questions were set in order to obtain the research aims:

1) Do pre-service teachers perceive science as a creative subject?

2) Do pre-service teachers view science as a creative subject when compared with other subjects?

3) What are the contextual elements that affect the process of fostering creativity in the science classroom?

4) What are the characteristics of creative students in the science classroom, according to pre-service teachers? 


\subsection{Significance of the Study}

Some significant conclusions can be drawn from this study. Firstly, the findings of the current study will contribute in understanding how science teachers perceive creativity in science within the Kuwaiti context. Secondly, the findings also can provide suggestions for developing the science teacher program at the College of Basic Education. Thirdly, it may inform the research community of science education about aspect, strategies, and factors that are associated with creativity in the science classroom, especially, when previous literature acknowledges the lack of studies in this area of study.

\section{Methods}

\subsection{Data Collection}

To elicit trainee-science teachers' understanding of creativity in science education, a questionnaire was used in order to collect data. The questionnaire, entitled "Teacher's views about creativity in science" was developed by the researchers. It comprises, sequentially, five demographic questions, nine closed-ended questions about creativity in education, nine closed-ended questions about creativity in science education specifically, and eight open-ended questions. The participants were asked to rate their perceptions using a 5-point Likert scale ranging from 'strongly agree' to 'strongly disagree'.

\subsection{Sample}

The questionnaire was distributed by hand to 185 Kuwaiti pre-service student science teachers at the College of Basic Education in Kuwait. The return rate was almost 82\%: 152 individuals responded to the questionnaire. This sample comprised 92 female $(60.5 \%)$ and 60 male $(39.5 \%)$ science teachers. The student teachers ranged from under 18 years old to over 30 years old. The questionnaire sample included all the students enrolled in the bachelor's degree in science education, including first year (12.5\%), second year (28.9\%), third year (32.9\%) and fourth year (25.7\%). In terms of the students' grade point average for the student major (GPA), respondents were divided up into five groupings: 3.5 or more (32.2\%), 3-3.49 GPA (25.7\%), 2.5-2.99 GPA (22.4\%), 2-2.49 GPA $(10.5 \%)$, and less than 2 GPA $(10.5 \%)$.

\subsection{Validity and Reliability}

The study followed steps for ensuring the validity and reliability of the questionnaire. For example, the researchers reviewed similar instruments from related literature, such as Alsahou (2015), Hong and Kang (2010), Lee and Kim (2005), Liu and Lin (2014), Newton and Newton (2009, 2011), Park, Lee, and Oliver (2006), and Lederman, Abd-Elkhalick, and Schwartz (2002). Then, the initial questionnaire was examined and reviewed by three experts in creative and gifted education.

Regarding reliability, a pilot study was conducted in order to examine the internal reliability. The pilot questionnaire was completed by 27 participants. It originally consisted of 20 closed-ended items; two items were dropped in order to reach acceptable scores for the sub-scales.

Table 1. Reliability test of the sub-scales of the questionnaire

\begin{tabular}{lccc}
\hline Scale & N & Cronbach's Alpha & N of Items \\
\hline Total views of creativity in science education & & .822 & 18 \\
Sub-scale: Views of creative education & 27 & .722 & 9 \\
Sub-scale: Views of creativity in the science subject & .706 & 9 \\
\hline
\end{tabular}

As shown in Table 1, a reliability analysis was carried out on the total views of creativity in science education scale, comprising 18 items. Cronbach's alpha showed the questionnaire to reach acceptable reliability, $\alpha=0.822$ (J. Gliem \& R. Gliem, 2003). The sub-scale of views on creative education reaches acceptable reliability, $\alpha=$ 0.722 ; meanwhile, the sub-scale of creativity in science subject also reaches acceptable reliability, $\alpha=0.706$.

\subsection{Data Analysis}

The quantitative data collected from the questionnaires was analyzed using SPSS. Descriptive statistics were used including means, standard deviations, frequencies, and percentages. With respect to qualitative data, open-ended questions were analyzed using an iterative process. Qualitative data sources were coded to discern initial patterns and themes, which were continually refined and modified during the analysis to generate both descriptive and explanatory categories (Lincoln \& Guba, 1985). Codes were developed to identify relevant and recurring themes. 


\section{Results}

\subsection{Quantitative Findings}

Quantitative data analysis revealed some the teachers' beliefs about the nature of the science subject and how they view it. It also shows how they perceive creativity in education in general, and how they rank the science subject as creative when compared with other subjects. Thus, the quantitative results answer the first two research questions as follows.

Table 2. Total means of the sub-scales

\begin{tabular}{lccccc}
\hline Sub-scales & $\mathrm{N}$ & Minimum & Maximum & $M$ & $S D$ \\
\hline Pre-service teachers' views of creative education & 152 & 2.78 & 4.89 & 4.03 & .42 \\
Pre-service teachers' views of creativity in the science subject & 152 & 2.56 & 4.78 & 3.76 & .39 \\
\hline
\end{tabular}

Table 2 shows that the two sub-scales are close to the agreement level. The grand average for participants' views toward creative education is 4.03 , with standard deviation .42. Meanwhile, pre-service teachers' views of creativity in science scored a lower mean $(M=3.76, S D=.39)$. Further details of the two sub-scale items are discussed below.

Table 3. Pre-service science teachers' views of creativity in education

\begin{tabular}{|c|c|c|c|c|c|c|c|c|}
\hline $\begin{array}{l}\mathrm{N} \text { of } \\
\text { item }\end{array}$ & Item & $\begin{array}{c}\text { Strongly } \\
\text { disagree } \\
\mathrm{N}(\%)\end{array}$ & $\begin{array}{l}\text { Disagree } \\
\text { N (\%) }\end{array}$ & $\begin{array}{c}\text { Neutral } \\
\mathrm{N}(\%)\end{array}$ & $\begin{array}{l}\text { Agree } \\
\text { N (\%) }\end{array}$ & $\begin{array}{c}\text { Strongly } \\
\text { agree } \\
\text { N (\%) }\end{array}$ & $M$ & $S D$ \\
\hline 1 & $\begin{array}{l}\text { Creativity is a skill that can be applied to every } \\
\text { domain of knowledge }\end{array}$ & $\begin{array}{c}2 \\
(1.3)\end{array}$ & $\begin{array}{c}8 \\
(5.3)\end{array}$ & $\begin{array}{c}14 \\
(9.2)\end{array}$ & $\begin{array}{c}82 \\
(53.9)\end{array}$ & $46(30.3)$ & 4.07 & .85 \\
\hline 2 & $\begin{array}{l}\text { Creativity is a skill that can be applied to every } \\
\text { school subject }\end{array}$ & $\begin{array}{c}2 \\
(1.3)\end{array}$ & $19(12.7)$ & $\begin{array}{c}33 \\
(21.7)\end{array}$ & $\begin{array}{c}52 \\
(34.2)\end{array}$ & $46(30.3)$ & 3.80 & 1.05 \\
\hline 3 & $\begin{array}{l}\text { Creativity is a fundamental skill to be developed } \\
\text { in school }\end{array}$ & $\begin{array}{c}0 \\
(0)\end{array}$ & $\begin{array}{c}5 \\
(3.3)\end{array}$ & $\begin{array}{c}28 \\
(18.4)\end{array}$ & $\begin{array}{c}65 \\
(42.8)\end{array}$ & $54(35.5)$ & 4.11 & .815 \\
\hline 4 & Everyone can be creative & $\begin{array}{c}8 \\
(5.3)\end{array}$ & $31(20.4)$ & $\begin{array}{c}30 \\
(19.7)\end{array}$ & $\begin{array}{c}42 \\
(27.6)\end{array}$ & $\begin{array}{c}41 \\
(27)\end{array}$ & 3.51 & 1.23 \\
\hline 5 & Creativity can be taught in science & $\begin{array}{c}0 \\
(0)\end{array}$ & $\begin{array}{c}9 \\
(5.9)\end{array}$ & $\begin{array}{c}24 \\
(15.8)\end{array}$ & $\begin{array}{c}75 \\
(49.3)\end{array}$ & $44(28.9)$ & 4.01 & .83 \\
\hline 10 & $\begin{array}{l}\text { Creative outcomes are new things for the } \\
\text { individual and peers in the classroom }\end{array}$ & $\begin{array}{c}0 \\
(0)\end{array}$ & $\begin{array}{c}10 \\
(6.6)\end{array}$ & $\begin{array}{c}22 \\
(14.5)\end{array}$ & $76(50)$ & $44(28.9)$ & 4.01 & .838 \\
\hline 11 & $\begin{array}{l}\text { Creative results are the production of what is } \\
\text { new on a personal level }\end{array}$ & $\begin{array}{c}0 \\
(0)\end{array}$ & $\begin{array}{c}11 \\
(7.2)\end{array}$ & $\begin{array}{c}21 \\
(13.8)\end{array}$ & $\begin{array}{c}74 \\
(48.7)\end{array}$ & $46(30.3)$ & 4.02 & .857 \\
\hline 18 & $\begin{array}{l}\text { Classroom teacher is responsible for helping } \\
\text { students develop creativity }\end{array}$ & $\begin{array}{c}2 \\
(1.3)\end{array}$ & $\begin{array}{c}5 \\
(3.3)\end{array}$ & $\begin{array}{c}19 \\
(12.5)\end{array}$ & $\begin{array}{c}72 \\
(47.4)\end{array}$ & $54(35.5)$ & 4.13 & .85 \\
\hline 20 & $\begin{array}{l}\text { The teacher should use methods that enhance } \\
\text { student creativity and imagination }\end{array}$ & $\begin{array}{c}0 \\
(0)\end{array}$ & $\begin{array}{c}0 \\
(0)\end{array}$ & $\begin{array}{c}8 \\
(5.3)\end{array}$ & $\begin{array}{c}47 \\
(30.9)\end{array}$ & $97(63.8)$ & 4.59 & .592 \\
\hline
\end{tabular}

From the table it can be deduced that the means of most of the items of this dimension are located in the agreement level: means ranged between 3.51 and 4.59. Only two items scored means below 4 . Item 4 has the lowest score $(M=3.51, S D=1.23)$ followed by item $2(M=3.80, S D=1.05)$. Meanwhile, the means of the remaining items were above 4 ; and item 20 was the highest $(M=4.59, S D=0.59)$. From the means of the items it can be concluded that the participants agreed that creativity is a fundamental ability that should be fostered in school subjects. Also, it indicates that all students can demonstrate creative endeavors by producing new ideas. Thus, participants agreed that teachers are responsible for developing the creative skills of students and creating encouraging classroom activities.

The other sub-scale of the questionnaire demonstrates pre-service teachers' views of creativity in the science subject. As shown in Table 4, most of the means reached the agreement level and ranged between 3.78 to 4.3 , except items 8 and 12 which scored slightly low means $(M=2.74, S D=1.13$; and $M=2.84, S D=1.11$ respectively). The results in Table 4 indicate that participants agreed that creativity is important for constructing 
scientific knowledge and that it should be developed in science. They also agreed that the science subject is a creative one, and teaching and learning it should focus on developing the students' creative abilities.

Table 4. Pre-service science teachers' views of creativity in the science subject

\begin{tabular}{|c|c|c|c|c|c|c|c|c|}
\hline $\mathrm{N}$ & item & $\begin{array}{c}\text { Strongly } \\
\text { disagree } \\
\mathrm{N}(\%)\end{array}$ & $\begin{array}{c}\text { Disagree } \\
\mathrm{N}(\%)\end{array}$ & $\begin{array}{c}\text { Neutral } \\
\mathrm{N}(\%)\end{array}$ & $\begin{array}{l}\text { Agree } \\
\text { N }(\%)\end{array}$ & $\begin{array}{c}\text { Strongly } \\
\text { agree } \\
\text { N (\%) }\end{array}$ & $M$ & $S D$ \\
\hline 6 & Creativity in science can be assessed & $\begin{array}{c}1 \\
(.7)\end{array}$ & $\begin{array}{c}9 \\
(5.9)\end{array}$ & $\begin{array}{c}27 \\
(17.8)\end{array}$ & $73(48)$ & $42(27.6)$ & 3.96 & .868 \\
\hline 8 & Creativity in science can be seen by everyone & $\begin{array}{c}19 \\
(12.5)\end{array}$ & $\begin{array}{c}50 \\
(32.9)\end{array}$ & $\begin{array}{c}47 \\
(30.9)\end{array}$ & $\begin{array}{c}23 \\
(15.1)\end{array}$ & $\begin{array}{c}13 \\
(8.6)\end{array}$ & 2.74 & 1.13 \\
\hline 9 & $\begin{array}{l}\text { Creativity and imagination are essential elements in } \\
\text { the formation of scientific knowledge }\end{array}$ & $\begin{array}{c}3 \\
(2)\end{array}$ & $\begin{array}{c}6 \\
(3.9)\end{array}$ & $\begin{array}{c}28 \\
(18.4)\end{array}$ & $\begin{array}{c}68 \\
(44.7)\end{array}$ & $47(30.9)$ & 3.99 & .913 \\
\hline 12 & $\begin{array}{l}\text { Creative outcomes are not necessarily original and } \\
\text { new products** }\end{array}$ & $\begin{array}{c}16 \\
(10.5)\end{array}$ & $\begin{array}{c}49 \\
(32.2)\end{array}$ & $\begin{array}{c}42 \\
(27.6)\end{array}$ & $\begin{array}{c}34 \\
(22.4)\end{array}$ & $\begin{array}{c}11 \\
(7.2)\end{array}$ & 2.84 & 1.11 \\
\hline 13 & $\begin{array}{l}\text { Creativity is only in the fields of visual arts, music, } \\
\text { drama and artistic performance** }\end{array}$ & $\begin{array}{c}1 \\
(.7)\end{array}$ & $\begin{array}{c}13 \\
(8.6)\end{array}$ & $\begin{array}{c}10 \\
(6.6)\end{array}$ & $\begin{array}{c}59 \\
(38.8)\end{array}$ & $69(45.4)$ & 4.19 & .94 \\
\hline 15 & $\begin{array}{l}\text { Science contributions facilitate the development of } \\
\text { creativity }\end{array}$ & $\begin{array}{c}3 \\
(2)\end{array}$ & $\begin{array}{c}7 \\
(4.6)\end{array}$ & $\begin{array}{c}39 \\
(25.7)\end{array}$ & $\begin{array}{c}74 \\
(48.7)\end{array}$ & $29(19.1)$ & 3.78 & .876 \\
\hline 16 & $\begin{array}{l}\text { Science teachers must have knowledge about } \\
\text { creativity }\end{array}$ & $\begin{array}{c}0 \\
(0)\end{array}$ & $\begin{array}{l}3 \\
(2)\end{array}$ & $\begin{array}{c}24 \\
(15.8)\end{array}$ & $\begin{array}{c}64 \\
(42.1)\end{array}$ & $61(40.1)$ & 4.2 & .78 \\
\hline 17 & $\begin{array}{l}\text { Creativity is essential for the development of the } \\
\text { educational level of students in science }\end{array}$ & $\begin{array}{c}2 \\
(1.3)\end{array}$ & $\begin{array}{c}8 \\
(5.3)\end{array}$ & $\begin{array}{c}33 \\
(21.7)\end{array}$ & $73(48)$ & $36(23.7)$ & 3.88 & .88 \\
\hline 19 & $\begin{array}{l}\text { Fostering creativity is essential to improving the } \\
\text { educational performance of students in science }\end{array}$ & $\begin{array}{c}0 \\
(0)\end{array}$ & $\begin{array}{c}4 \\
(2.6)\end{array}$ & $\begin{array}{c}13 \\
(8.6)\end{array}$ & $\begin{array}{c}67 \\
(44.1)\end{array}$ & $68(44.7)$ & 4.3 & .74 \\
\hline
\end{tabular}

** recoded data of negative items.

Moreover, participants' views about the science subject are revealed. The result indicated that the majority of participants believed that science is a creative subject. As shown in Table 5, 68.4\% of the pre-service science teachers viewed science as a subject that can support creativity. In contrast, a few of the participants viewed science as not a subject which can promote creativity $(\mathrm{N}=4,2.6 \%)$. About a quarter of the participants believed that the science subject is sometimes creative $(\mathrm{N}=39,25.7 \%)$.

Table 5. Pre-service science teachers' views of science as a creative subject

\begin{tabular}{lcc}
\hline Response & Frequency & Percent \\
\hline Yes, science is a creative subject & 104 & 68.4 \\
No, science is not a creative subject & 4 & 2.6 \\
Sometimes & 39 & 25.7 \\
I do not know & 5 & 3.3 \\
Total & 152 & 100.0 \\
\hline
\end{tabular}

The participants were asked to put school subjects in order, starting from the most creative to the least creative subject. The results indicated that science is one of the most creative subjects, as shown the table below. 
Table 6 . Student teachers' order of the subjects which are connected more with creativity

\begin{tabular}{|c|c|c|c|c|c|c|c|c|c|}
\hline Subject & $\begin{array}{c}\text { First } \\
\text { Count (\%) }\end{array}$ & $\begin{array}{c}\text { Second } \\
\text { Count (\%) }\end{array}$ & $\begin{array}{c}\text { Third } \\
\text { Count (\%) }\end{array}$ & $\begin{array}{c}\text { Fourth } \\
\text { Count (\%) }\end{array}$ & $\begin{array}{c}\text { Fifth } \\
\text { Count (\%) }\end{array}$ & $\begin{array}{c}\text { Sixth } \\
\text { Count (\%) }\end{array}$ & $\begin{array}{c}\text { Seventh } \\
\text { Count (\%) }\end{array}$ & $\mathrm{M}(\mathrm{SD})$ & Order \\
\hline Fine Arts & $\begin{array}{c}71 \\
(46.7)\end{array}$ & $\begin{array}{c}24 \\
(15.8)\end{array}$ & $\begin{array}{c}14 \\
(9.2)\end{array}$ & $\begin{array}{c}12 \\
(7.9)\end{array}$ & $\begin{array}{c}11 \\
(7.2)\end{array}$ & $\begin{array}{c}15 \\
(9.9)\end{array}$ & $\begin{array}{c}5 \\
(3.3)\end{array}$ & $2.56(1.91)$ & 1 \\
\hline Science & $\begin{array}{c}34 \\
(22.4)\end{array}$ & $\begin{array}{c}29 \\
(19.1)\end{array}$ & $\begin{array}{c}44 \\
(28.9)\end{array}$ & $\begin{array}{c}23 \\
(15.1)\end{array}$ & $\begin{array}{c}11 \\
(7.2)\end{array}$ & $\begin{array}{c}8 \\
(5.3)\end{array}$ & $\begin{array}{c}3 \\
(2)\end{array}$ & $2.89(1.52)$ & 2 \\
\hline Music & $\begin{array}{c}13 \\
(8.6)\end{array}$ & $\begin{array}{c}53 \\
(34.9)\end{array}$ & $\begin{array}{c}28 \\
(18.4)\end{array}$ & $\begin{array}{c}21 \\
(13.8)\end{array}$ & $\begin{array}{c}6 \\
(3.9)\end{array}$ & $\begin{array}{c}13 \\
(8.6)\end{array}$ & $\begin{array}{c}18 \\
(11.8)\end{array}$ & $3.43(1.87)$ & 3 \\
\hline Mathematics & $\begin{array}{c}22 \\
(14.5)\end{array}$ & $\begin{array}{c}28 \\
(18.4)\end{array}$ & $\begin{array}{c}31 \\
(20.4)\end{array}$ & $\begin{array}{c}37 \\
(24.3)\end{array}$ & $\begin{array}{c}9 \\
(5.9)\end{array}$ & $\begin{array}{c}14 \\
(9.2)\end{array}$ & $\begin{array}{c}11 \\
(7.2)\end{array}$ & $3.45(1.75)$ & 4 \\
\hline Arabic & $\begin{array}{c}11 \\
(7.2)\end{array}$ & $\begin{array}{c}2 \\
(1.3)\end{array}$ & $\begin{array}{c}21 \\
(13.8)\end{array}$ & $\begin{array}{c}23 \\
(15.1)\end{array}$ & $\begin{array}{c}41 \\
(27)\end{array}$ & $\begin{array}{c}39 \\
(25.7)\end{array}$ & $\begin{array}{c}15 \\
(9.9)\end{array}$ & $\begin{array}{c}4.7 \\
(1.59)\end{array}$ & 5 \\
\hline History & $\begin{array}{c}1 \\
(.7)\end{array}$ & $\begin{array}{c}8 \\
(5.3)\end{array}$ & $\begin{array}{c}11 \\
(7.2)\end{array}$ & $\begin{array}{c}18 \\
(11.8)\end{array}$ & $\begin{array}{c}34 \\
(22.4)\end{array}$ & $\begin{array}{c}24 \\
(15.8)\end{array}$ & $\begin{array}{c}56( \\
36.8)\end{array}$ & $5.45(1.56)$ & 6 \\
\hline English & $\begin{array}{c}1 \\
(.7)\end{array}$ & $\begin{array}{c}7 \\
(4.6)\end{array}$ & $\begin{array}{c}4 \\
(2.6)\end{array}$ & $\begin{array}{c}15 \\
(9.9)\end{array}$ & $\begin{array}{c}42 \\
(27.6)\end{array}$ & $\begin{array}{c}42 \\
(27.6)\end{array}$ & $\begin{array}{c}41 \\
(27)\end{array}$ & $\begin{array}{c}5.5 \\
(1.36)\end{array}$ & 7 \\
\hline
\end{tabular}

Note. The subjects are gradually ordered. The lowest mean represents the first and the highest mean represents the last subject.

As shown in Table 6, pre-service science teachers considered subjects like Fine Arts and Science to be the most connected with creativity, with a sequential priority mean of 2.56 and 2.89 respectively. Music and Math took the middle position with priority means of 3.43 and 3.45. Arabic, History and English came last, with sequential priority means of $4.7,5.45$, and 5.5 respectively.

\subsection{Qualitative Findings}

Inductive coding analysis was applied to create themes from participants' responses to eight open-ended questions. Four major themes emerged from the analysis: 1) the meaning of scientific creativity,2) participants' views on the science subject, 3) creative students in the science subject, 4) reinforcements and challenges to creative students in the science subject.

\subsubsection{Meaning of Scientific Creativity}

Four categories appeared under the meaning of scientific creativity: originality, usefulness, imagination, and empiricism. The codes of these categories indicate that most of the participants viewed scientific creativity as imaginative thinking based on empirical actions to create something new, socially useful, and scientifically acceptable.

Firstly, almost all the participants believed that scientific creativity means being original, such as creating new things or solving scientific problems through new ways. Originality is seen as "the ability of creating, or ... of solving something in a creative manner, that differs from the traditional way of solving" (participant1). Secondly, almost one third of the participants stated that the outcome should be useful. Creativity is "a new and useful production that is appreciated by the community and it solves a particular problem" (participant 8). "It should be not only new but also useful for others" (participant 33). Thirdly, creativity requires imaginative thinking about natural phenomena; as one said, scientific creativity is "scientific imagination that is based on theories, research, and experiments" (participant 21). Creativity is "imagination, and it's thinking of what's new, or developing something [from] traditional to new" (participant 96). Various participants stated that imagination is a fundamental ability of scientific creativity, because "the starting point of scientific creativity is imagination" (participant 28). Finally, scientific creativity is based on empirical actions and evidences. Creativity as domain-specific shall be compatible with the domain principles; therefore, scientific creativity relies on empirical activities, explanations, and evidences. One participant said, "All sciences were created by creative endeavors" (participant 58); another one said that creativity is "a new idea or production that can be proved scientifically through experimentations" (participant 73). One participant who referred to empiricism in their responses defined scientific creativity as "any creation that is based on valid empirical work and scientific evidence" (participant 139).

\subsubsection{Pre-Service Teachers' Views on the Science Subject}

The findings revealed that participants view science as a creative and contextual subject. It is creative because it 
focuses on building different thinking skills and encourages students to thinking logically and experimentally.

Students can be creative when they do science. Science is natural knowledge based on humanitarian effort; such effort includes observing natural phenomena, recording changes, creating a hypothesis, conducting experiments, logically judging, explaining the phenomena, and predicting future changes. (participant 11)

Table 7. Participants' views on the science subject

\begin{tabular}{|c|c|c|c|}
\hline Theme & Category & Codes & Frequency $(\mathrm{n}=152)$ \\
\hline \multirow{5}{*}{ Science subject } & \multirow{4}{*}{ Creative subject } & Encourages students' imagination & 8 \\
\hline & & Develops creative thinking skills & 62 \\
\hline & & Develops critical thinking skills & 9 \\
\hline & & Develops problem-solving skills & 35 \\
\hline & Contextual subject & Scientific knowledge develops students' daily life & 120 \\
\hline
\end{tabular}

The participants frequently asserted that "science activities encourage students' imagination" (participant 21), and "enable them to think creatively" (participant 9). Also, they perceived that "scientific research consists of imagination and experimentation." (participant 31)

As shown in Table 7, the majority of pre-service teachers (120 out of 152) believed that science is a contextual subject, meaning that it is a subject that is rooted in daily life. Some said that science activities and information are strongly connected with the students' lives.

Science is everywhere in students' daily activities. When they go to the family doctor they talk about biological things, when they change light bulbs at home they actually practice the lessons of electricity, when they see their mothers cook they remember chemistry lessons, and so on. Thus, if creativity is fostered in the science classroom, [students] would possibly be able to generate new things in their daily lives. (participant 151)

Pre-service teachers frequently stated the usefulness of science activities in the students' context. They believed that the activities of the science classroom "can be directly applied in after-school life." (participant 22)

\subsubsection{Creative Students in the Science Classroom}

The inductive analysis revealed categories related to creative students' behaviors in science activities, as illustrated in Table 8.

Table 8. Creative students in the science subject

\begin{tabular}{|c|c|c|c|}
\hline Theme & Category & $\begin{array}{l}\text { Frequency } \\
(\mathrm{n}=152)\end{array}$ & Exemplary codes \\
\hline \multirow{5}{*}{$\begin{array}{l}\text { Creative } \\
\text { students' } \\
\text { behaviors }\end{array}$} & $\begin{array}{l}\text { Enthusiasm to learn } \\
\text { scientific topics }\end{array}$ & 64 & $\begin{array}{c}\text { "Creative ones are always concerned with scientific topics, that's why } \\
\text { they like to search and explore" (participant 39) }\end{array}$ \\
\hline & Curiosity & 49 & $\begin{array}{l}\text { “Creative students are usually interested in finding answers by } \\
\text { themselves. They are very keen to learn more” (participant 53) }\end{array}$ \\
\hline & $\begin{array}{l}\text { Commitment to discover } \\
\text { things by his own efforts }\end{array}$ & 32 & $\begin{array}{l}\text { "When he fails many times, he does not give up, rather he tries again } \\
\text { until he reaches his goal" (participant 74) }\end{array}$ \\
\hline & $\begin{array}{l}\text { Experimenting: unusual } \\
\text { ideas }\end{array}$ & 20 & $\begin{array}{l}\text { "A creative student generates unfamiliar ideas for conducting the } \\
\text { practical activities. He likes to experiment with things and draw } \\
\text { conclusions" (participant 37) }\end{array}$ \\
\hline & Posing unfamiliar questions & 35 & $\begin{array}{l}\text { "Unexpected questions are linked with creative people. A creative } \\
\text { student asks many questions that are unusual ones" (participant 42) }\end{array}$ \\
\hline
\end{tabular}

Students' excitement to learn about scientific phenomena was mentioned by 64 participants. They indicated that creative students are enthusiastic when they learn something new. They also show great degrees of commitment and curiosity. Moreover, 35 participants indicated that questioning is one of the common behaviors of creative students; others indicated that creative students like to experiment with things and examine ideas. 
Table 9. Reinforcements and challenges of fostering creativity in science

\begin{tabular}{|c|c|c|c|c|}
\hline Theme & Category & Codes & $\begin{array}{l}\text { Frequency } \\
(\mathrm{n}=152)\end{array}$ & Exemplary code \\
\hline \multirow{7}{*}{$\begin{array}{l}\text { Fostering } \\
\text { creativity in } \\
\text { science }\end{array}$} & \multirow{6}{*}{ Reinforcements } & $\begin{array}{l}\text { Focusing on empirical } \\
\text { activities }\end{array}$ & 66 & $\begin{array}{l}\text { "We should let students experiment their ideas" } \\
\text { (participant 107) }\end{array}$ \\
\hline & & $\begin{array}{l}\text { Effective classroom } \\
\text { activities }\end{array}$ & 39 & $\begin{array}{l}\text { "Applying activities that help students to think out of } \\
\text { the box" (participant 62) } \\
\text { "Discussion, posing questions, testing ideas are } \\
\text { effective activities for creativity" (participant 30) }\end{array}$ \\
\hline & & CPD on creativity & 57 & $\begin{array}{l}\text { “To foster creativity, science teachers need } \\
\text { workshops on creativity" (participant 114) }\end{array}$ \\
\hline & & $\begin{array}{l}\text { Providing instructional } \\
\text { tools and materials }\end{array}$ & 32 & $\begin{array}{l}\text { "Creativity in science requires a rich laboratory room } \\
\text { with tools and assistant aids" (participant 109) }\end{array}$ \\
\hline & & \multirow{2}{*}{$\begin{array}{l}\text { Encourage students' } \\
\text { autonomy to learn science }\end{array}$} & \multirow[t]{2}{*}{23} & $\begin{array}{c}\text { "When a student comes up with a small creative idea, } \\
\text { we should encourage him to develop his idea" } \\
\text { (participant } 74 \text { ) }\end{array}$ \\
\hline & & & & $\begin{array}{l}\text { "Students' autonomy is important because ... creative } \\
\text { thinking needs free thinking" (participant 65) }\end{array}$ \\
\hline & Challenges & $\begin{array}{l}\text { Consuming a lot of time } \\
\text { and effort }\end{array}$ & 32 & $\begin{array}{l}\text { "Promoting creativity in science is a hard mission } \\
\text { because it consumes a lot of time and hard work" } \\
\text { (participant } 25 \text { ) }\end{array}$ \\
\hline
\end{tabular}

\subsubsection{Reinforcements and Challenges}

As illustrated in Table 9, factors impacting the promotion of creativity in the science classroom were generated from the data analysis. The most common facilitator is focusing on empirical activities, where students are able to test their own hypothesis and ideas. Also, the student teachers frequently mentioned the role of CPD courses that would focus on creativity. Such courses would provide teachers with ideas, and ways to apply them in practice in the science class. Moreover, they believed that the classroom should be generously supplied with tools and materials to enable students to practice ideas and apply various activities. Some student teachers mentioned that students' autonomy should be encouraged by supporting free thinking and freedom to explore their hypotheses.

\section{Discussion}

\subsection{Views on Creative Education}

The current findings show that the pre-service teachers hold advanced views regarding creative education $(\mathrm{M}=$ 4.03). The pre-service teachers agreed that creativity can be applied in all subjects including science. Also, they agreed that creativity is a potential which can be demonstrated by anyone. In other words, they disagreed with the view that holds creativity to be a distinctive ability of gifted people. Also, they agreed that creativity can be demonstrated in class when students show creative actions and ideas. Such a result is in line with the model of everyday creativity also known as the little c model (Boden, 1990; Craft, 2002).

\subsection{Views on Creativity in Science Education}

The findings also revealed that pre-service teachers realize the science subject is a creative one when compared with other subjects. They believe that science contributes in developing different thinking skills such as creative thinking, problem solving, and critical thinking; and that such skills are embedded in teaching and constructing scientific knowledge. Thus, the majority (68\%) stated that science is a creative subject; while $25 \%$ said it is sometimes creative. Few teachers said that science is not creative ( 4 out of 152 participants). They ordered science as one of the most creative subjects; they view art as the most creative subject, followed by science. These findings are compatible with the result of some studies, (Alsahou, 2015; Hu \& Adey, 2002; Johnston, 2009; Johnston \& Ahtee, 2006). For example, Johnston (2009) concluded that teachers specializing in teaching scientific topics such as chemistry, physics, and geology believe that creative endeavors can be developed in their subjects. They see creativity as one of the fundamental elements of the nature of scientific knowledge (Alsahou, 2015; Hu \& Adey, 2002; Johnston \& Ahtee, 2006).

Nevertheless, this result contradicted the findings of other studies that concluded that teachers mainly relate creativity with art, such as the visual arts and music (Aljughaiman \& Mowrer-Reynolds, 2005; Diakidoy \& Kanari, 
1999; Fryer, 1996; Kampylis, 2010; Mohammed, 2006). Such a contradiction could be explained by the differences between the sample of the current study and the samples of the contradicted studies; in which, current research focused on pre-service teachers specializing in science, whereas the contradicted ones focused on general teachers.

\subsection{Meaning of Scientific Creativity}

The findings revealed four aspects for conceptualizing something as creative: originality, usefulness, imagination, and empiricism. Originality as an example was mentioned by almost all participants. Usefulness was mentioned by 51 pre-service teachers, and imagination by 38 . Such an understanding of creativity is in line with the descriptions stated by a number of creativity scholars, such as Feldman (1994), Amabile (1983), Sternberg and Lubart (1999), Lynch and Harries (2001), and Kampylis, Berki, and Saariluoma (2009). Further, almost all the participants added empiricism as fundamental for scientific creativity. Empiricism appeared to be an aspect that explains the scientific part of the definition of scientific creativity. This result illustrates that anything considered as scientifically creative should be empirically accepted.

\subsection{Views on Creative Students}

The results described creative students in science classes as curious, tolerant, and enthusiastic. This description is compatible with the literature of creativity that defines creative people (Burnard et al., 2006; Dacey, 1989; Feist, 1998; Starko, 1995, 2001; Taylor, 1995; Torrance, 2004). Other characteristics mentioned inquiry: the findings indicated that creative students in science class usually pose unfamiliar questions and tend to test and experiment these questions. Questioning skills can foster students' creativity and enhance individuals' potential to be creative in science class. This finding is in line with other studies (Burnard et al., 2008; Chappell et al., 2008a, 2008b; Craft et al., 2012a, 2012b). As Haigh (2007) stated, questioning skills must be nurtured for producing creative conclusions.

Therefore, pre-service teachers believe that creative students should not only question things but also examine them scientifically. They emphasized that experiments and practical lab activities stimulate creative students to find new possibilities for unfamiliar questions and ideas. This finding concurs with findings from other research (e.g., Cheng, 2006; Haigh, 2007; P. Kind \& V. Kind, 2007; Newton \& Newton, 2008, 2010; Shayer \& Adey, 2002).

\subsection{Views on Impact Factors}

Some factors appeared to be external ones, such as the availability of various tools and equipment in school labs. The participants believe that classroom activities are influenced by the Ministry of Education, which is responsible for equipping school labs with educational materials and tools. Also, they believe that their practices for fostering creativity will be affected by the CPD courses provided by the Ministry. These two external factors play a role in employing approaches to creativity.

Empirical and creative thinking depend on interactions within the science classroom. The results indicate some factors relating to the teachers' practices in class, such as focusing on effective activities that encourage creative thinking, including hand-on activities. This view is in line with some studies (e.g., Alsahou, 2015; Haigh, 2007; P. Kind \& V. Kind, 2007). Related literature confirms that students will creatively involve themselves in the processes of conducting scientific research (Craft, 2000; Meador, 2003; Starko, 2010). The result also emphasized on developing students' autonomy because it helps students to think differently and creatively. The correlation between creativity and students' autonomy is supported by previous research (Alsahou, 2015; Ewing \& Gibson, 2007; Haring-Smith, 2006; Jeffry \& Wood, 1997; Mohammed, 2006).

The most common challenges that would constrain science teachers from applying practices for creativity is a lack of time and the hard work required for implementing creative interactions. They believe that aiming for creativity will require a lot of effort and time (Alsahou, 2015).

\section{Conclusion}

The pre-service teachers hold positive views about creativity in science. They agree that creativity should be fostered in the science class. They defined scientific creativity and identified the factors for facilitating the process of nurturing creativity in science activities. Thus, it can be concluded that they hold a general understanding of and positive attitude toward creativity in the science class.

\section{Implications and Further Research}

Some implications can be derived from the current study. For example, the Ministry of Education can improve teachers' practices for scientific creativity by offering CPDcourses on scientific creativity and creative 
pedagogies. Also, school labs could be reinforced with various tools and materials. The student teacher training college should offer courses about creative education and scientific creativity to pre-service science teachers.

Future research can build on the conclusions of this study to investigate questions not addressed in this research with pre-service teachers. Future research could compare pre-service science teachers with in-service teachers. Such research will inform the student teacher training college about the differences. Second, future research may explore teachers' conceptions of scientific creativity and their views of the NoS. This may offer exploratory and explanatory findings of how teachers perceive the NoS and creativity.

\section{References}

Abd-Elkhalick, F., \& Lederman, N. G. (2000). Improving science teachers' conceptions of the nature of science: a critical review of the literature. International Journal of Science Education, 22(7), 665-701. https://doi.org/10.1080/09500690050044044

Aljughaiman, A., \& Mowrer-Reynolds, E. (2005). Teachers' conceptions of creativity and creative students. Journal of Creative Behavior, 39(1), 17-34. https://doi.org/10.1002/j.2162-6057.2005.tb01247.x

Alsahou, H. (2015). Teachers' beliefs about creativity and practices for fostering creativity in science classroom in the State of Kuwait ( $\mathrm{PhD}$ thesis, University of Exeter).

Amabile, T. (1983). The social psychology of creativity. New York: Springer-Verlag. https://doi.org/10.1007/978-1-4612-5533-8

Andiliou, A., \& Murphy, P. K. (2010). Examining variations among researchers' and teachers' conceptualizations of creativity: A review and synthesis of contemporary research. Educational Research Review, 5, 201-219. https://doi.org/10.1016/j.edurev.2010.07.003

Beghetto, R. A. (2006). Creative justice? The relationship between prospective teachers' prior schooling experiences and perceived importance of promoting student creativity. Journal of Creative Behavior, 40, 149-162. https://doi.org/10.1002/j.2162-6057.2006.tb01270.x

Boden, M. (1990). The Creative Mind: Myths and Mechanisms. Weidenfield \& Nicolson.

Burnard, P. Craft, A., Cremin, T., Chappell, K. (2008). Developing methodology for exploring 'creative learning' and 'possibility thinking'. Paper presented at American Educational Research Association annual meeting, New York.

Burnard, P., Craft, A., \& Grainger, T. (2006). Possibility thinking. International Journal of Early Years Education. 14(3), 243-262. https://doi.org/10.1080/09669760600880001

Chappell, K., Craft, A., Burnard, P., \& Cremin, T. (2008a). Features of 'possibility thinking' in fostering creative learning. Paper given at American Educational Research Association annual meeting, New York.

Chappell, K., Craft, A., Burnard, P., \& Cremin, T. (2008b). Question-posing and question responding: The heart of 'possibility thinking' in the early years. Early Years, 28(3), 267-86. https://doi.org/10.1080/09575140802224477

Cheng, V. M. Y. (2006). A comprehensive curriculum framework for infusing creativity learning into physics knowledge learning. College Physics, 18(3), 15-19.

Craft, A. (2002). Creativity and early years education: A life wide foundation. London, New York: Continuum.

Craft, A., Cremin, T., Burnard, P., Dragovic, T., Chappell, K. (2012a): Possibility thinking: Culminative studies of an evidence-based concept driving creativity? International Journal of Primary, Elementary and Early Years Education, 3(13), 1-19. https://doi.org/10.1080/03004279.2012.656671

Craft, A., McConnon, L., \& Matthews. A. (2012b). Creativity and child-initiated play: Fostering possibility thinking in four-year-olds. Thinking Skills and Creativity, 3(3), 241-245. https://doi.org/10.1016/j.tsc.2008.09.006

Dacey, J. (1989). Fundamentals of creative thinking. Lexington, Massachusetts: D. C. Health and Company.

Diakidoy, I. N., \& Kanari, E. (1999). Student teachers' beliefs about creativity. British Educational Research Journal, 25, 225-243. https://doi.org/10.1080/0141192990250206

Ewing, R., \& Gibson, R. (2007). Creative teaching or teaching creatively? Using creative arts strategies in pre-service teacher education. Waikato Journal of Education, 13, 161-179. https://doi.org/10.15663/wje.v13i1.284 
Feist, G. J. (1998). A meta-analysis of personality in scientific and artistic creativity. Personality and Social Psychology Review, 4, 290-309. https://doi.org/10.1207/s15327957pspr0204_5

Feldman, D. (1994). Creativity: Proof that development occurs. In D. Feldman, M. Csikszentmihalyi, \& H. Gardner (Eds.), Changing the World: A framework for the study of creativity (pp. 159-172). Westport, CT: Praeger.

Fryer, M. (1996). Creative teaching and learning. London: Paul Chapman Publishing, Ltd.

Gliem, J., \& Gliem, R. (2003). Calculating, interpreting, and reporting Cronbach's Alpha Reliability Coefficient for Likert-Type Scales. A paper Presented at the Midwest Research-to-Practice Conference in Adult, Continuing, and Community Education, The Ohio State University, Columbus, OH, October 8-10, 200.

Grant, T., Clark, U., Reershemius, G., Pollard, D., Hayes, S., \& Plappert, G. (2017). Quantitative Research Methods for Linguists. Florence: Taylor and Francis. https://doi.org/10.4324/9781315181707

Haigh, M. A. (2007). Can investigative practical work in high school biology foster creativity? Research in Science Education, 37, 123-140. https://doi.org/10.1007/s11165-006-9018-5

Haring-Smith, T. (2006). Creativity research review: Some lessons for higher education. Peer Review, 8(2), 23-30.

Hennessey, B. A., \& Amabile, T. M. (2010). Creativity. Annual Review of Psychology, 61, 569-598. https://doi.org/10.1146/annurev.psych.093008.100416

Hong, N., \& Kang, N. (2010). South Korean and the US secondary school science teachers' conception of creativity and teaching for creativity. International Journal of Science and Mathematics Education, 8, 821-843. https://doi.org/10.1007/s10763-009-9188-5

Hu, W., \& Adey, P. (2002). A scientific creativity test for secondary school students. International Journal of Science Education, 24(4), 389-404. https://doi.org/10.1080/09500690110098912

Jeffrey, B., \& Woods, P. (1997). The Relevance of Creative Teaching: Pupils' views. In A. Pollard, D. Thiessen, \& A. Filer (Eds.), Children and their Curriculum: The perspectives of primary and elementary children (pp. 15-33). London: Falmer. https://doi.org/10.4324/9780203454329_chapter_1

Johnston, J. (2009). What is Creativity in Science Education. In A. Wilson (Ed.), Creativity in Primary Education (2nd ed.). Exeter: Learning Matters.

Johnston, J., \& Ahtee, M. (2006). What are primary student teachers' attitudes, subject knowledge and pedagogical content knowledge needs in a physics topic? Teaching and Teacher Education, 22(4), 1-10. https://doi.org/10.1016/j.tate.2005.11.015

Kampylis, P. (2010). Fostering creative thinking-The role of primary teachers. Jyväskylä Studies in Computing. Jyväskylä, Finland: University of Jyväskylä.

Kampylis, P., Berki, E., \& Saariluoma, P. (2009). In-service and prospective teachers' conceptions of creativity. Thinking Skills and Creativity, 4(1), 15-29. https://doi.org/10.1016/j.tsc.2008.10.001

Kind, P. M., \& Kind, V. (2007). Creativity in science education: Perspectives and challenges for developing school science. Studies in Science Education, 43, 1-37. https://doi.org/10.1080/03057260708560225

Lederman, N. G., Abd-Elkhalick, F., Bell, R. L., \& Schwartz, R. S. (2002). Views of nature of science questionnaire (VNOS): Toward valid and meaningful assessment of learners' conceptions of nature of science. Journal of Research in Science Teaching, 39, 497-521. https://doi.org/10.1002/tea.10034

Lee, E. A., \& Kim, K. H. (2005). Korean Science Teachers' Understanding of Creativity in Gifted Education. The Journal of Secondary Gifted Education, 2(3), 98-105. https://doi.org/10.4219/jsge-2005-476

Lin, C., Hu, W., Adey, P., \& Shen, J. (2003). The influence of case on scientific creativity. Research in Science Education, 33, 143-162. https://doi.org/10.1023/A:1025078600616

Lincoln, Y. S., \& Guba, E.G. (1985). Naturalistic inquiry. Beverly Hills, CA: Sage. https://doi.org/10.1016/0147-1767(85)90062-8

Liu, S., \& Lin, H. (2014). Primary Teachers' beliefs about Scientific Creativity in the Classroom Context. $\begin{array}{llll}\text { International Journal of Science } & \text { Education, 36(10), }\end{array}$ https://doi.org/10.1080/09500693.2013.868619

Lynch, M. D., \& Harries, C. R. (2001). Fostering creativity in children K-8: Theory and practice. Boston: Allyn 
\& Bacon.

Meador, K. S. (2003). Thinking creatively about science: Suggestions for primary teachers. Gifted Child Today, 26(1), 25-29. https://doi.org/10.4219/gct-2003-93

Mohammed, B. (2006). Promoting creativity in early childhood education in Brunei (PhD thesis, University of Western Australia).

Newton, D. P. (2010). Assessing the creativity of scientific explanations in elementary science: an insider-outsider view of intuitive assessment in the hypothesis space. Research in Science and Technological Education, 28(3), 187-201. https://doi.org/10.1080/02635143.2010.501752

Newton, D. P., \& Newton, L. D. (2009). Some student teachers' conceptions of creativity in school science. Research in Science and Technological Education, 27(1), 45-60. https://doi.org/10.1080/02635140802658842

Newton, D. P., \& Newton, L. D. (2011). Engaging science: Pre-service primary school teachers' notions of engaging science lessons. International Journal of Science \& Mathematics Education, 9(2), $327-345$. https://doi.org/10.1007/s10763-010-9244-1

Osborne, J., \& Dillon, J. (2008). Science education in Europe: Critical reflections. London: The Nuffield Foundation.

Pajares, M. F. (1992). Teachers' beliefs and educational research: Cleaning up a messy construct. Review of Educational Research, 62(3), 307-332. https://doi.org/10.2307/1170741

Park, S., Lee, S., Oliver, J. S., \& Crammond, B. (2006). Changes in Korean science teachers' perception of creativity and science teaching after participating in an overseas professional development program. Journal of Science Teacher Education, 17, 37-64. https://doi.org/10.1007/s10972-006-9009-4

Pratt, D. (1992). Conceptions of teaching. Adult Education Quarterly, 42(4), $203-220$. https://doi.org/10.1177/074171369204200401

Richardson, V. (1996). The role of attitudes and beliefs in learning to teach. In J. Sikula (Ed.), Handbook of research on teacher education (pp. 102-119). New York: Simon and Schuster Macmillan.

Shayer, M., \& Adey, P. (2002). Learning Intelligence. Milton Keynes: Open University Press.

Shin, S., \& Koh, M. (2007). A cross-cultural study of teachers' beliefs and strategies on classroom behavior management in urban American and Korean school systems. Education and Urban Society, 39(2), $286-309$. https://doi.org/10.1177/0013124506295280

Starko, A. J. (1995). Creativity in the classroom. White Plains, NY: Longman.

Starko, A. J. (2001). Creativity in the classroom: Schools of curious delight (2nd ed.). London: Lawrence Erlbaum Associates Publishers.

Starko, A. J. (2010). Creativity in the classroom: Schools of curious delight (4th ed.). New York: Routledge. https://doi.org/10.4324/9780203871492

Sternberg, R. J., \& Lubart, T. I. (1999). The concept of creativity: Prospects and paradigms. In R. J. Sternberg (Ed.), Handbook of creativity (pp. 3-15). New York: Cambridge University Press. https://doi.org/10.1017/cbo9780511807916.003

Taylor, C. (1995). Various approaches to and definitions of creativity. In R. Sternberg (Ed.), The nature of creativity. Cambridge: Cambridge University Press.

Thompson, A. (1992). Teachers' beliefs and conceptions: A synthesis of the research. In D. Grouws (Ed.), Handbook of research on mathematics teaching and learning (pp. 127-146). New York: Macmillan.

Torrance, E. (2004). Great expectations: Creative achievements of the sociometric stars in a 30-year study. The Journal of Secondary Gifted Education, 16(1), 5-13. https://doi.org/10.4219/jsge-2004-465

Woolley, S. L., Benjamin, W. J. J., \& Woolley, A. W. (2004). Construct validity of a self-report measure of teacher beliefs related to constructivist and traditional approaches to teaching and learning. Educational and Psychological Measurement, 64, 319-331. https://doi.org/10.1177/0013164403261189 


\section{Copyrights}

Copyright for this article is retained by the author(s), with first publication rights granted to the journal.

This is an open-access article distributed under the terms and conditions of the Creative Commons Attribution license (http://creativecommons.org/licenses/by/4.0/). 